\title{
A Labyrinth Game for Blind Children Using Problem Solving Learning Model
}

\author{
https://doi.org/10.3991/ijet.v15i02.11375 \\ Lala Septem Riza ( $\left.{ }^{\varpi}\right)$, Tyas Sawiji, Nurjanah \\ Universitas Pendidikan Indonesia, Bandung, Indonesia \\ lala.s.riza@upi.edu \\ Haviluddin, Edy Budiman \\ Universitas Mulawarman, Samarinda, Indonesia \\ Alejandro Rosales-Pérez \\ Tecnologico de Monterrey, Monterrey, Mexico
}

\begin{abstract}
This research aims to design the concept of learning media for the blind student and apply it to labyrinth game using problem-solving learning model. To design this media, 21 blind child characteristics, learning model, lesson plan and story concept of the game have been considered. After developing the proposed learning media, some experiments on blind students are conducted. Then, the results of the experiments are processed and analyzed based on qualitative method. They shows that scores, perspectives, and focus of users are good. It means that the proposed learning media provides a positive impact on the blind child. Moreover, guidance and direction to students are the important things that have to do when the media is applied.
\end{abstract}

Keywords-Blind student, problem solving model, labyrinth game

\section{Introduction}

Based on global data on vision problems in the World Health Organization (WHO) in 2010, the number of people experiencing visual impairments in the world was 285 million, 39 million experienced blindness and 246 million had low vision. Based on the age range of 0-14 years that suffered blindness is 1,421 million people while in the age range of $15-49$ years is around 5,784 million. In Indonesia according to the National Statistics Agency in 2007, the highest percentage of types of disability in the age range of 24-59 months was blind, which is equal to $0,17 \%$.

In this age range children need education for future life supplies. While each type of disability experienced by a person certainly has different characteristics from normal people. Characteristics of blind people according to research conducted by Zittel et al [1] can be seen in aspects of motor development, social and psychosocial adjustment. Rahardja [2] describes the characteristics of blind people with different 
perspectives, namely cognitive characteristics, academic characteristics, social emotional characteristics and behavioral characteristics.

Based on the characteristics possessed by the blind, special schools are needed as educational facilities. Suriawati, et al. [3] stated that the school of special education was prepared as an educational institution to handle and provide special education services for people with special needs. The meaning of 'special' is in fact just a general learning need and the so-called special method or special service referred to above is nothing more than a quality method that is focused on the needs of children [4]. The first school for blind children in Europe was founded in 1784 and in England opened in 1891 followed by schools in Edinburgh, Bristol, London and other major cities. In Indonesia blind children are given special school facilities, namely part A of extraordinary schools [2].

The extraordinary schools are prepared to improve the cognitive of blind children. The cognitive development of blind children tends to be hampered compared to normal children in general. This is due to cognitive development is not closely related to intelligence or intelligence capabilities, but also with the ability to sense vision. To support teaching and learning activities for blind children in special schools several tools were developed.

Based on several studies that have been carried out assistive devices to support teaching and learning activities. The use of problem solving learning models to solve math problems is very helpful for students in learning. Carvalho et al [5] developed an audio-based puzzle game for the visually impaired. The puzzle game was tested on 13 blind people consisting of 8 women and 8 men. Puzzle games can be played by blind people because they are assisted with audio. Sanchez [6] designed a model for interactive learning environments for children with impaired vision. Ahmad and Firdaus [7] explained cartoon films to blind children with narratives in explaining the appearance of cartoons. Borges and Tome [8] developed music learning for students' blind people with interactive learning strategies using software. Lucic et al. [9] built a lugram game using computers for blind children in geometry subjects for 4th graders with an average age of 10 years in Serbia. With the many examples of media that have been developed in previous studies, it is necessary to design concepts and the development of the latest learning media as one of the innovations and means to assist the difficulties experienced by blind children.

Therefore, this study intends to design concepts and build educational games for blind children with the help of learning models. Games in multimedia learning that will be implemented by the author are labyrinth-shaped games, where players will be placed in a place and players must find a way out by passing obstacles in it. This labyrinth game is used to deliver material on civic education subjects with all sound directions in the game. The labyrinth game considers four aspects, namely: the characteristics of the blind, the problem solving learning model, the Lesson Plan and the concept of the story.

Learning that uses game learning media certainly still requires the use of learning models. The use of this learning model aims to keep learning focused so that it can achieve learning objectives effectively and efficiently. The learning model that will be applied in the game as a learning media is the problem solving learning model. 
The problem solving learning model is a teaching model that emphasizes the ability to think about how to solve problems and process information [10]. In the world of education, problem solving is often associated with problem solving in the types of tasks given to students. There are 4 steps that are often used in problem solving, namely:

- Understanding the problem

- Develop a plan

- Implement the plan

- Re-checking [10]

Problem solving learning models have several advantages, namely developing students' ability to think creatively to solve problems correctly, solve problems realistically, improve student learning activities, help students to develop new knowledge and be responsible in learning, and provide opportunities for students to apply knowledge they have in the real world. Using problem solving in teaching and learning can familiarize students to face and solve problems skillfully.

\section{Research Methodology}

In order to develop the model, we divide the research procedures into three steps: designing concept, developing the labyrinth game, and the experiments. Firstly in the concept stage, we conducted a literature study regarding the characteristics of blind children to better know how blind children, knowing the personality condition of blind children, and characteristics in learning activities of children with visual impairments. After conducting a literature study on the characteristics of the blind, a literature study of the Labyrinth Runner novel will be used as a guide in making adventure stories in games that will be developed. Regarding learning methods with the intention of knowing what learning methods are used during teaching and learning activities. After conducting a literature study, we conducted a survey to the school of special education for get a problem related to the learning process of blind students concerning material that is difficult to teach, the difficulties faced by blind children in learning, and media that are often used in learning. Regarding the school of special education curriculum, we need to know the programs carried out by teachers and students in the teaching and learning process concerning all aspects both related to knowledge or subject matter, evaluations given and the activities of students and teachers.

In the development of the Labyrinth Game stage, we build multimedia that is carried out according to the linear sequential model. Analysis and design are adopted from the design concept of learning media. The implementation phase of the game is made with the Construct 2 application. After the media is finished, then there are 2 tests, namely the black-box test and validation by experts.

The final stage, which is the experimentation, is used for validating the model and application. First, a research scenario is made so that the research is more directed and clear. Then carry out research or experiments in accordance with the scenario and 
apply the media that has been made. From the implementation of the research or experiment will produce results that will then be analyzed and processed in accordance with qualitative methods and draw conclusions from the results that have been analyzed. After obtaining all the data, a draft is made on research or experiments that have been carried out as physical evidence that the researcher has conducted research or experiments, so that it can be read by everyone and as a reference for developing further learning research.

After developing the application, we perform an experiment carried out in the school of special education in Bandung. The population and research sample are determined as follows:

- Population: Students in the Bandung in the seventh grade in the school of special education with a total of 5 students aged 12-13 years.

- Samples: We select the samples with purposive sampling technique.

Then, we conducted an interview to all students; and the qualitative method is used for analysis the data.

\section{Design and Implementation Game}

\subsection{Labyrinth design games}

The labyrinth game for blind children is different from common children because blind children have visual impairments, so they use the sense of hearing and touch to replace the sense of sight as the main channel for receiving information. The design of the labyrinth game made in this study is based on 4 aspects, namely:

- Characteristics of the labyrinth game for the blind

- Problem solving learning model

- Lesson plan scenario

- A concept of the labyrinth game story.

Characteristics of the labyrinth game for the blind: Basically, in this stage, we attempt to analysis the characteristics of multimedia for blind students, so that the proposed application can be suitable to them. Analysis can be done by reviewing some related articles from literature. These aspects can be grouped into types of colors, audio, text, hardware, and games. The following is an explanation of the characteristics of the proposed multimedia for students with special needs who are visually impaired:

1) Types of color: First, we always use the highest contrast and use bright letters (white or light yellow) on a dark or dark black background or dark letters on a light or white background [11]. The more striking the color difference between objects and the background, the higher the contrast. The use of contrasting colors and brighter lighting will help low vision. Then, high resolution is needed for complex applications [12]. Bright and reflective solid colors can be easily seen such as red, orange and yellow, while groups of colors that are dif- 
ficult to see include (a) Old blue, brown, and black; (b) Blue, green, and purple; and (c) Pink, yellow and pale green.

2) Types of audio: Hearing of blind children is like a normal child, but it would be better if they experience blindness since childhood [13]. Lowest frequency limit which is safe for hearing $60 \mathrm{~dB}$ but they can hear with a frequency of 32 $\mathrm{dB}$ weak or whispering sounds [14].

3) Text: The use of upper and lower case letters in the text makes it easier than using italics or underscores [11]. Font types are used to more easily recognize characters such as Arial, Comic Sans, Verdana, and Tahoma. The font size 8$12 \mathrm{pt}$ is only seen in part by the blind, sometimes it is needed by the blind to read clearly. Sometimes low vision can read with a font size of 18pt. So that low vision people can read a computer monitor, the writing must be enlarged or made to appear large. Text that has a distance of adjacent letters will make blind people with reading difficulties, spaces needed to help blind people to read (i.e., 1.5 space) [11]. The use of simple words makes it easy for blind people to absorb information and narratives [7].

4) Hardware: Games that can be accessed by the blind using a keyboard, joystick and mouse. There are several types of keyboards based on the number of keys: 84 key keyboards, 101 keys, 106 keys, etc. Cursor is a pointer on the monitor screen that shows the computer user where the letter to be typed will appear. The cursor button can move the cursor left or right per letter or per word, up or down per line, per screen or per page, and to the beginning or to the end of a line.

5) Game: Games that are suitable for the visually impaired are audio-based games because blind people will be helped by audio in the game [5].

Problem solving learning model: The design of this learning media is not only adjusted to the media characteristics of blind children, but also adjusted to the stages in the problem solving learning model. The learning model consists of 4 stages, as follows:

1) Compare the problem: At this stage the teacher gives problems to be solved by students. The problem given at this stage is an adventure story that must be resolved and answers are sought. Students must analyze the problem given by the teacher. Then students are asked to listen to adventure stories available in the media.

2) Revise a plan: At this stage the teacher provides instructions that can be used to solve the problem. After the teacher gives direction, students are asked to plan the strategy that will be used. In the media students are asked to listen to instructions in the form of a button on the keyboard that can be used.

3) Caring out the plan: At this stage the teacher brings students to solve problems according to the instructions given. Students look for data as a support for problem solving. Students look for answers to problems given. In the media students are asked to find a way out of the labyrinth and look for information related to learning material.

4) Reflexive: In this stage students are asked to work on an evaluation of the learning material to find out whether all the steps that have been taken have 
been completed. Students provide conclusions about answers to problems that have been resolved. In the media this stage is not included but is done through interviews with students.

Lesson plan scenario of the labyrinth game: This labyrinth game is a learning media for Pancasila and Citizenship Education material in the chapter on the Pancasila formulation process. The purpose of this learning is for students to understand the process of formulating the Pancasila from the initial formation of BPUPKI, PPKI, the basis of the State formulated by Sopeomo, the basis of the State formulated by M. Yamin, and the basis of the State formulated by Ir. Soekarno.

This game consists of 5 adventure places that must be sought out. Each place consists of material formulation process Pancasila. At the end of learning students will be given evaluation questions through interview activities carried out by the teacher with a total of 20 questions.

Concepts of the labyrinth game story: The concept of the story raised in the development of a labyrinth game for blind children was taken from the novel The Labyrinth Runner written by James Dashner. The novel was published in 2009, then made into a film in 2014. The story in the novel is an attempt by a group of teenagers to get out of the mysterious labyrinth and Thomas is the main character in the story.

From the story summary of the novel The Labyrinth Runner, the concept of a labyrinth game for blind children will be made. The concept of the story that will be developed in the game labyrinth is similar to stories in novels but, equipped with characteristics of blind children, learning models and Lesson Plan.

The main character in the game named Thomas and accompanied by his younger brother named Teresa. Thomas and Teresa are trapped in a labyrinth in a forest in a remote village. Thomas needs help getting out through the labyrinth because he is blind. Teresa will guide directing the exit from the labyrinth. Problems encountered besides the time they were required to seek information about the process of formulating the Pancasila. The trip out of the labyrinth is divided into 5 places and is only given 15 minutes for each place. If it exceeds the time given then, the player will repeat the game from a place that has run out of time. This labyrinth game will be played by blind children, so all the directions in the game are sound. The game is played using a computer and only uses the keyboard for each movement and movement.

\section{Implementation}

At this stage includes the creation of media interfaces according to the media design and needs that have been analyzed previously. The application or software implementation is developed in accordance with the flowchart and storyboard that have been created and validated by experts. Figure 1 is the learning media interface that has been created. 


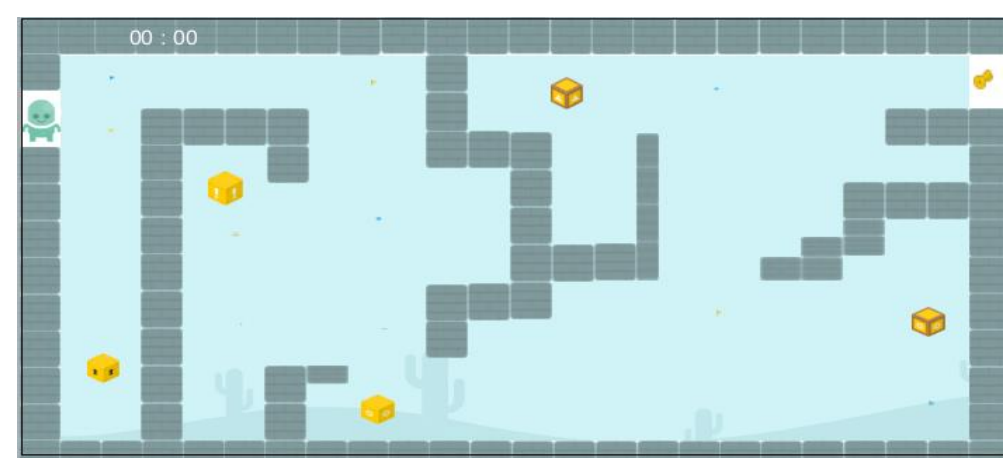

Fig. 1. GUI of labyrinth game 1

Figure 1 is a labyrinth 1 media learning interface for blind children. It is the first place for users to find a way out. The material to look for in the labyrinth 1 is BPUPKI material. To search for information and material on BPUPKI users must listen to the instructions delivered via audio in accordance with the literature study [12]. In this place users will be given Garuda Pancasila songs as a prefix, followed by instructions on where to go and use any key commands on the keyboard in accordance with literature studies [9]. Each yellow box contains information and material about BPUPKI. Yellow is used for the box so that it contrasts with the background color in place 1 according to [11]. The labyrinth is blue for the background and the wall is visible to male and female students according to the literature study [15]. Time will continue to run during the game, if time runs out it will start from the entrance. After the user gets all the information and material available, he can continue his journey to the second place by getting a yellow key at the end of the labyrinth 1 trip, the yellow color chosen for the key color according to [11]. This place is provided a warning if the user crashes into the barrier fortress by issuing a sound in accordance with the study of literature [12]. To add an impression to users that they are in the forest, they are equipped with some audio from the atmosphere of the forest in accordance with the study of literature [12].

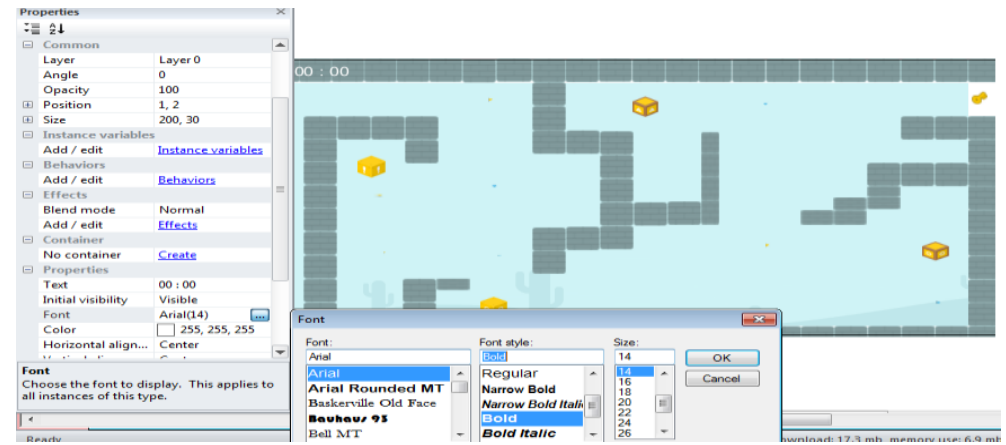

Fig. 2. Text implementation in labyrinth game 1 
In Figure 2, there is an implementation of the text for the time in the labyrinth game, there are properties columns used for setting the screen and letters used. The writing on the instructions page uses the Arial font type with the font size of $14 \mathrm{pt}$ based on [11].

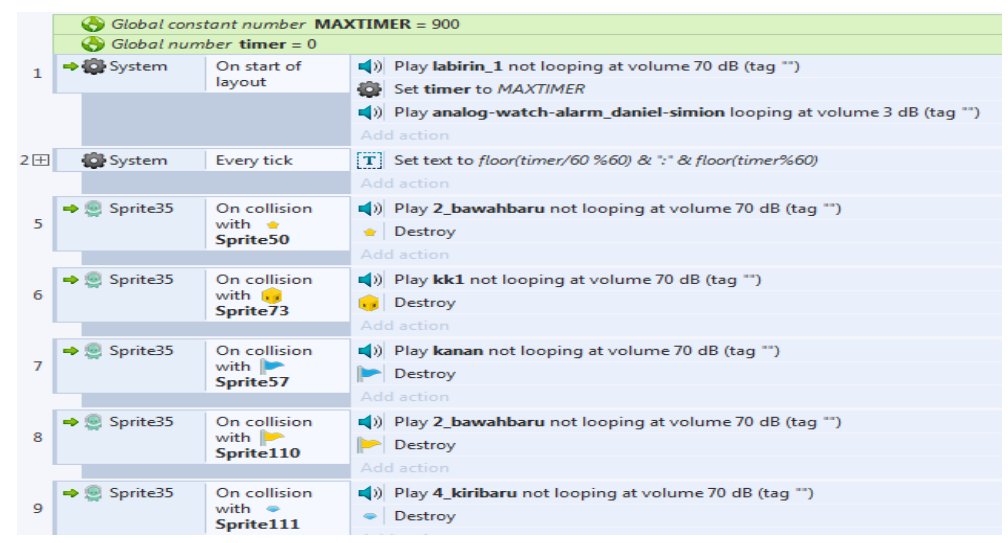

Fig. 3. Audio and keyboard implementation in labyrinth game 1

Figure 3 shows the audio implementation on the labyrinth page. 1 global constant number means that the time to complete one place is maximum given 900 seconds or 15 minutes and global number timer means that time starts at 0 . The first line means that when the labyrinth page 1 starts to open a labyrinth_1.ogg sound will be heard with a frequency of $70 \mathrm{~dB}$ according to the literature study [14]. The second line is the time setting to change from minute to second. The third line to nine is audio according to [12] which will be heard when playing labyrinth games and each of them is heard with a frequency of $70 \mathrm{~dB}$ in accordance with the literature study [14]. To play on the labyrinth page 1 using the arrow key commands on the keyboard adapted to [9].

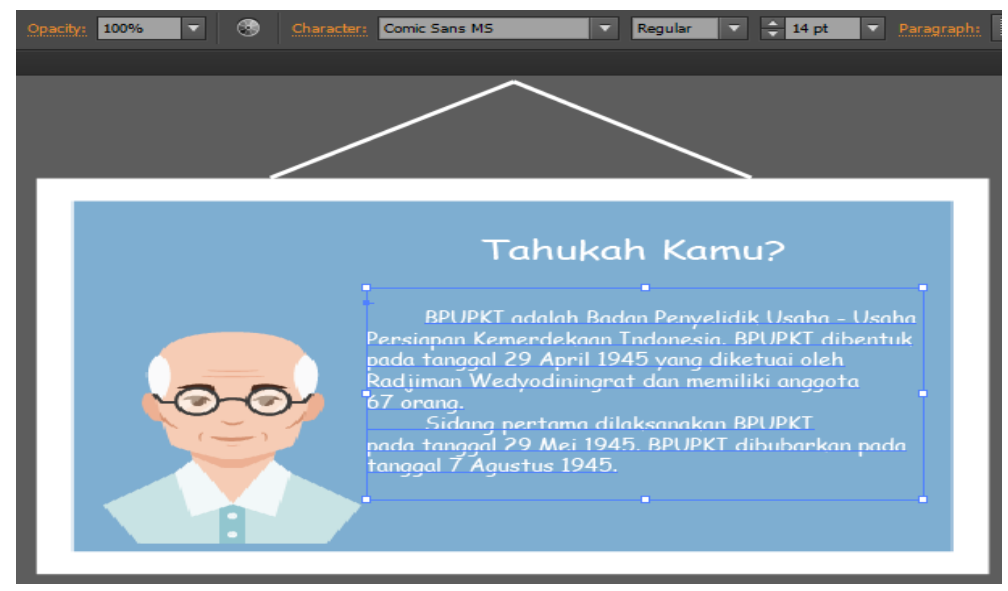

Fig. 4. Text material implementation in labyrinth game 1 
Figure 4 shows the implementation of BPUPKI material texts in the media, on the labyrinth page 1 the writing uses the Comic Sans font type based on [11]. Font style used regularly based on [11]. Blue and white colors are used so that the contrast and appearance of low vision. The text uses 1.5 spaces to make it easy to read according to [11].

\section{$5 \quad$ Results}

Experiments carried out in this study were conducted at the school of special education in Bandung. The population and research sample are determined as follows:

- Population: Are students in the Bandung VII grade in the school of special education with a total of 5 students aged 12-13 years.

- Samples: In this study sample selection techniques using purposive sampling technique.

After the experiment, the researcher conducted an interview to all students and obtained the following results:

\subsection{Use of computer media}

Interviews regarding the use of computer media that were asked to students obtained results as in Table 1.

Table 1. Use of computer media labyrinth games

\begin{tabular}{|c|l|l|}
\hline No & Student name & $\begin{array}{r}\text { Feedback of the following question: Whether the maze game is used easily or } \\
\text { no? If it is difficult which part is difficult? }\end{array}$ \\
\hline 1 & DCL & At first it was difficult, but if it was often played it was easy. \\
\hline 2 & LA & Yes it's okay, but I'm confused if it's stuck in the wrong direction \\
\hline 3 & MH & It is easy \\
\hline 4 & NR & Yes, it is easy \\
\hline 5 & RNS & Yes, it is relatively easy \\
\hline
\end{tabular}

Table 1 shows that students in general can play labyrinth games easily, but each student has their own difficulties as experienced by LA who are confused if they have misdirected and hit the labyrinthine fortress.

\subsection{Emotional feelings when playing a labyrinth game}

In order to find out how the emotional feelings of students in playing games can be seen in Table 2. 
Table 2. Feedbacks showing students' emotional feeling

\begin{tabular}{|c|l|l|l|l|}
\hline No & $\begin{array}{c}\text { Student } \\
\text { name }\end{array}$ & $\begin{array}{l}\text { Did you get upset after } \\
\text { playing this game? }\end{array}$ & \multicolumn{1}{|c|}{ Are you bored? Why? } & $\begin{array}{l}\text { After playing the labyrinth } \\
\text { game, do you feel exciting? }\end{array}$ \\
\hline 1 & DCL & $\begin{array}{l}\text { If you have clicked the } \\
\text { arrow direction button } \\
\text { instead of crashing }\end{array}$ & $\begin{array}{l}\text { It's not boring, it's crowded } \\
\text { but there is an audio part } \\
\text { that is obviously clear }\end{array}$ & $\begin{array}{l}\text { Enthusiastic, not bad if the } \\
\text { teacher hasn't arrived yet can be } \\
\text { played first }\end{array}$ \\
\hline 2 & LA & Upset if stuck everywhere & Excited & Get excited \\
\hline 3 & MH & Upset if I am stuck & Good & Get excited \\
\hline 4 & NR & Funny & No, I am happy & Yes, I am getting excited \\
\hline 5 & RNS & No, It is great & No & I want to learn more \\
\hline
\end{tabular}

\subsection{Duration for completing the game}

The average duration of students completing one place can be seen in Table 3 . It shows that students can complete one place with an average duration of less than 15 minutes.

Table 3. Observation of the average of the time duration

\begin{tabular}{|c|l|l|}
\hline No & Student name & \multicolumn{1}{c|}{ Average } \\
\hline 1 & DCL & Each place can be completed in 13 minutes \\
\hline 2 & LA & Complete one place with 10 minutes \\
\hline 3 & MH & Complete one place with a time of 14 minutes \\
\hline 4 & NR & Complete one place with a time of 13 minutes \\
\hline 5 & RNS & Complete one place with 10 minutes \\
\hline
\end{tabular}

\subsection{Knowledge and attitude assessment}

Assessment of knowledge and attitudes was obtained from the results of the pretest and posttest given by the teacher through interviews and results can be seen in Table 4. It shows that in terms of attitudes $\mathrm{MH}$ is less responsible for the work given, while the other four students are responsible for the work given. In terms of knowledge after using the media three children experienced an increase in grades and two other children were stable from the beginning to the end, two children were stable in learning, namely LA and RNS, this was due to learning without media they had gained a stable score.

Table 4. Assessment of the attitudes and attitudes of blind students

\begin{tabular}{|c|l|l|c|c|}
\hline \multirow{2}{*}{ No } & \multirow{2}{*}{ Student name } & \multicolumn{2}{|c|}{ Evaluation of Attitude } & \multicolumn{2}{|c|}{ Evaluation of Knowledge } \\
\cline { 3 - 4 } & & & Pretest & Posttest \\
\hline 1 & DCL & Responsibility for the work given & 80 & 100 \\
\hline 2 & LA & Responsibility for the work given & 100 & 100 \\
\hline 3 & MH & Less responsibly with the work given & 70 & 80 \\
\hline 4 & NR & Responsibility for the work given & 80 & 90 \\
\hline 5 & RNS & Responsibility for the work given & 100 & 100 \\
\hline
\end{tabular}




\section{Discussion}

The results of research in the field indicate that the use of instructional media that has been made is said to be suitable and has a positive impact on learning for blind children including:

\subsection{Use of learning media}

Students during learning have been given learning media to help the process of teaching and learning activities. Students have no difficulty when using learning media. The labyrinth games they have played have their own charm. The attraction that already exists in the labyrinth in terms of learning and adventure. Other challenges they have felt when playing appear from audio that supports the atmosphere in the forest.

\subsection{Audio that is in the labyrinth game}

Audio that has been used in this labyrinth game to support the atmosphere of the storyline and the delivery of the material for the Pancasila formulation process. The audio at the beginning of the story they have opened the game is quite clear and understandable. For the entire audio contained in the game it has been felt quite clearly but there are some parts that are not clearly articulated. The audio speed they have heard is felt enough and not too fast

\subsection{Material delivered in labyrinth games}

Learning material that has been incorporated into the game is the main attraction felt by students. The history of the Pancasila formulation process has been quite favored by all students. The history of the formation of Indonesia, the making of the Law and the process of formulating the Pancasila have become the material that students like. After carrying out Civics Learning using learning media in the form of labyrinth games, students have increased enthusiasm to return to studying PKn subjects.

\subsection{Emotional feelings felt by students}

Students' emotional feelings are illustrated when the learning process takes place, students have looked very enthusiastic and enthusiastic about learning in following the learning. Likewise, after being re-confirmed after the learning process was completed through interviews, all students had said the same thing that they enjoyed learning to use media and seen from the expressions of students when interviewed. 
6.5 Focus students listen to the instructions and duration of completing the game

Students who focus when listening to instructions in the labyrinth game have no difficulty finding a way out even though they are not accompanied by a teacher. While students who are not focused when listening to instructions will have difficulty playing and have used all the keys on the keyboard to move the character to find a way out so that the audio that is heard collides.

\subsection{Student assessment}

In general, the values that have been obtained from the five students in terms of attitudes are good because only one student is less responsible for the work given. However, in terms of knowledge from the test results, all students have shown improved results and some are stable due to the quality of children in learning is very good.

\section{Conclusion}

Based on the results of research and discussions that have been conducted that research on the development and implementation of learning media for blind children produces several conclusions including:

- In order to design and develop labyrinth games for blind children there are 4 aspects that need to be considered, namely: the characteristics of blind children, problem solving learning models, Lesson Plan and the concept of labyrinth game stories. The characteristics of blind children are used as a guide for developing games related to audio, color, text, the ability to operate computers and hardware used. The learning model is used so that the objectives of the learning to be carried out can be achieved. Lesson Plan is used as a guide to learning pathways that will be developed in the game. The concept of the labyrinth game story is used so that the storyline in the game is more focused in accordance with the concept of adventure. Furthermore, the labyrinth game that has been designed, developed and implemented has proven to be suitable and provides a positive impact felt by students after using the labyrinth game.

- The important thing during implementing learning media for blind children is to provide guidance and direction at all stages of learning for children with visual impairments because students cannot see so students only rely on their sense of hearing and touch to receive information. When, operating a learning media on a computer must be accompanied by an alert person (vision and hearing, normal) so that students have no difficulty. When implementing labyrinth games the aspects of the characteristics of blind children, problem solving learning models, Lesson Plan and the concept of labyrinth game stories need to be considered. The four aspects become a benchmark in implementing the labyrinth game for blind children on the subject of the Pancasila formulation process. 
- Students' responses to learning media developed positively and overall they enjoyed using learning media because they were interested in adventure stories in the forest and had to find a way out. When completing one place in the labyrinth game with the time given 15 minutes they are able to complete less than 15 minutes even the students request that the time be accelerated to 10 minutes. The results of the attitude and knowledge assessment showed that there was an increase after using the labyrinth game in the Pancasila formulation learning process. The labyrinth game makes all students excited to learn.

\section{$8 \quad$ References}

[1] Zittel, L., Pyfer, J., \& Auxter, D. (2016). Principles and Methods of Adapted Physical Education \& Recreation. Jones \& Bartlett Publishers.

[2] Rahardja, D. (2010). Sistem Pengajaran Modul Orientasi dan Mobilitas. Bandung: UPI Press.

[3] Suriawati, L. M., Desak, P. E. N. \& I Wayan, S. (2014). Efektivitas pembelajaran dengan media visual untuk meningkatkan hasil belajar siswa tuna rungu pokok bahasan pecahan senilai. Seminar Nasional Matematika, hlm. 165-170. https://doi.org/10.25273/jipm.v4i1.8 $\underline{35}$

[4] Stubbs, S. (2008). Inclusive Education. Where there are few resources. Oslo, The Atlas Alliance Publ.

[5] Carvalho, J., Guerreiro, T., Duarte, L., \& Carriço, L. (2012, July). Audio-based puzzle gaming for blind people. In Proceedings of the Mobile Accessibility Workshop at MobileHCI (MOBACC).

[6] Sánchez, J. (2007). A model to design interactive learning environments for children with visual disabilities. Education and Information Technologies, 12(3), 149-163. https://doi. org/10.1007/s10639-007-9039-3

[7] Ahmad, W. F. W., \& Firdus, S. B. (2013). Representing visual content of movie cartoons through narration for the visually impaired. In Computer Applications Technology (ICCAT), 2013 International Conference on (pp. 1-6). IEEE. https://doi.org/10.1109/iccat. 2013.6522042

[8] Borges, J. A., \& Tome, D. (2014). Teaching music to blind children: new strategies for teaching through interactive use of musibraille software. Procedia Computer Science, 27, 19-27. https://doi.org/10.1016/j.procs.2014.02.004

[9] Lucic, B., Sedlar, N. V., \& Delić, V. (2011). Computer game Lugram—version for blind children. Telfor Journal, 3(1), 54-59.

[10] Polya, G. (2014). How to solve it: A new aspect of mathematical method. Princeton university press.

[11] Wolffe, K. E., Sacks, S. Z., Corn, A. L., Erin, J. N., Huebner, K. M., \& Lewis, S. (2002). Teachers of students with visual impairments: what are they teaching?. Journal of visual Impairment and Blindness, 96(5), 293-304. https://doi.org/10.1177/0145482x0209600502

[12] Köhlmann, W. (2012). Identifying barriers to collaborative learning for the blind. In International Conference on Computers for Handicapped Persons (pp. 84-91). Springer, Berlin, Heidelberg.

[13] Gougoux, F., Lepore, F., Lassonde, M., Voss, P., Zatorre, R. J., \& Belin, P. (2004). Neuropsychology: pitch discrimination in the early blind. Nature, 430(6997), 309. https://doi. org/10.1038/430309a 
[14] Heffner, R. S., \& Heffner, H. E. (1992). Hearing and sound localization in blind mole rats (Spalax ehrenbergi). Hearing research, 62(2), 206-216. https://doi.org/10.1016/0378$\underline{5955(92) 90188-\mathrm{s}}$

[15] Birch, J. (2001). Diagnosis of Defective Colour Vision. Butterworth-Heinemann.

\section{Authors}

Lala Septem Riza is a lecturer of Department of Computer Science Education, Universitas Pendidikan Indonesia. His research interest is in learning media, machine learning for education, and data science.

Tyas Sawiji is a student of Department of Computer Science Education, Universitas Pendidikan Indonesia. Her final project was to develop learning media for students with special need. tyassawiji96@gmail.com

Nurjanah is a lecturer of Department of Mathematics Education, Universitas Pendidikan Indonesia. Her research interest is in developing learning media for mathematics students. nurjanah@upi.edu

Haviluddin is a lecturer at Faculty of Computer Science and Information Technology (CSIT), Mulawarman University, Indonesia, since 2002. He completed his Ph.D. in Computer Science from Universiti Malaysia Sabah, Malaysia in 2016. He is the coordinator of publication and intellectual property rights of Research Institute and Community Service of Mulawarman University. His research interest is in artificial intelligent area.haviluddin@unmul.ac.id

Edy Budiman is a lecturer at Faculty of Computer Science and Information Technology (CSIT), Mulawarman University, Indonesia, since 2012. He completed his Master in Informatics Engineering from Universitas Hasanuddin, Indonesia in 2010. His research interest is in mobile programming area.edybudiman.unmul@ gmail.com

Alejandro Rosales-Pérez works in the School of Engineering and Science, Tecnologico de Monterrey, Monterrey, Mexico.

Article submitted 2019-07-25. Resubmitted 2019-09-18. Final acceptance 2019-09-21. Final version published as submitted by the authors. 